\title{
Pyrolysis of Waste Plastics as an Effective Tool in Sustainable Environmental Waste Management
}

\author{
Ibe Kevin Ejiogu ${ }^{1,2, *}$, Uche Ibeneme ${ }^{2}$, Mosunmade Olukemi Aiyejagbara ${ }^{2}$, David Oyemachi ${ }^{3}$ \\ ${ }^{1}$ Department of Research, Development Processes and Operations, Nigerian Institute of Leather and Science Technology (NILEST), Zaria, \\ Nigeria \\ ${ }^{2}$ Department of Polymer Technology, Nigerian Institute of Leather and Science Technology (NILEST), Zaria, Nigeria \\ ${ }^{3}$ Department of Environmental Technology, Nigerian Institute of Leather and Science Technology (NILEST), Zaria, Nigeria
}

Email address:

Kevin.edu.research@gmail.com (I. K. Ejiogu)

${ }^{*}$ Corresponding author

\section{To cite this article:}

Ibe Kevin Ejiogu, Uche Ibeneme, Mosunmade Olukemi Aiyejagbara, David Oyemachi. Pyrolysis of Waste Plastics as an Effective Tool in Sustainable Environmental Waste Management. Modern Chemistry. Vol. 9, No. 2, 2021, pp. 33-39. doi: 10.11648/j.mc.20210902.11

Received: February 26, 2021; Accepted: March 11, 2021; Published: June 30, 2021

\begin{abstract}
High utilization of plastics in the society today have caused the presence of substantial quantity of waste plastics in the environment. The menace of these waste plastics in the environment leaves much to be desired. The negative impact of waste plastics in our society cannot be overemphasized. There is need to develop an efficient and cost effective method to manage waste plastics because traditional method such as recycling have been unsuccessful. Some of the disadvantages in recycling include inefficient method of sorting, time consuming, labour intensive, high demand for water and environmental pollution. Therefore, there is need to develop a more efficient and effective method to manage waste plastics. Waste to energy concept through pyrolysis has been identified as a very innovative method of managing these waste plastics. Through research it has been identified that oil from waste plastics through pyrolytic processes tend to have high calorific value and could be used as alternative fuel. This work explored a detailed review on the pyrolytic breakdown of waste plastics through thermal and catalytic degradation and factors that play a critical role in these processes. The end products after pyrolytic breakdown are oil, gaseous materials, and char. The most effective way of controlling the factors for the pyrolytic degradation of the waste plastic that will give optimal fuel production and increase yield for each kilogram of waste plastic was also an area of interest covered in this work.
\end{abstract}

Keywords: Pyrolysis, Waste Plastics, Degradation, Environmental Pollution

\section{Introduction}

Commodity plastics have increased tremendously due to the crucial role waste plastics plays in the environment today; increase in world population has also played a crucial role in the increasing demand of plastics to fulfill our day to day activity. According to studies the world production of plastics reached an alarming record high of about 299 million tons in 2013 showing an alarming increase of $4 \%$. The accumulation of waste plastics over time becomes geometric as most plastics are single use materials. About 25 million tons of waste plastics were recorded in Europe in 2012. Statistics also showed that about $38 \%, 26 \%$ and $36 \%$ went into landfill, recycling and energy recovery respectively [1]. This record showed an alarming high record of waste plastics in the landfills taking up a large chunk of space and creating land degradation since waste plastics are non degradable they create a negative impact on the land causing a negative impact on the lands and its environment.

The need to tackle the problems associated with waste plastics cannot be overemphasized as traditional methods such as recycling have failed over the years, thus the concept of waste to energy have through pyrolytic degradation taken centre stage. Pyrolytic degradation not only helps to remove the waste plastics from the environment but also helps to meet up the ever increasing world energy demand. Due to the polymeric composition of the plastics having been synthesized via polymerisation, various thermal treatment methods can be deployed to convert the plastics to fuel these 
include; pyrolytic degradation, controlled incineration, gasification and plasma process. Any of these processes can be deployed to tap into the rich calorific value of the waste plastics converted to valuable liquefied fuel [2]. Considering all the afore mentioned methods in the thermal treatment of waste plastics, researchers have taken a keen interest in pyrolytic degradation due to its flexibility, cost efficiency, lower energy requirements due to lower decomposition temperature and more energy can be recovered from the waste plastics $[2,3]$.

Pyrolysis which can be viewed as the opposite of polymerization is simply the thermal breakdown of large polymers molecules in this case waste plastics into smaller molecules, which are less complex. This thermal treatment is done in the absence of oxygen and applied for a short period of time $[4,5]$. The major products of pyrolysis are oil, gas and char which are utilized in the industries and refineries. Other very important viability of the pyrolytic process is its high yield $80 \mathrm{wt} \%$ liquid have been known to have been obtained and unlike convectional recycling, pyrolysis can handle highly contaminated stream of heterogeneous waste plastics which tremendously increases the flexibility of the process in the area of the feed stock. During Pyrolysis temperature of about $500{ }^{\circ} \mathrm{C}$ and pressure of about 1-2 atm are applied in the absence of oxygen. The waste plastic break down via the routes of de-polymerization or fragmentation, the route or path way that will be predominant during degradation may be determined by the complexity of the reactions that may be involved [6-8]. Other important advantages of pyrolysis are that process parameters can easily be manipulated to optimize the yield and the oil produced from this process can be used directly without further treatment [9]. More importantly the oil produced through pyrolysis of waste plastics tends to be more environmentally friendly as it contributes lower $\mathrm{CO}_{2}$ to the environment $[10,11]$.

Several researchers have done a lot of study on the utilization of pyrolysis technique on various plastics for fuel production. The quality and product yield is dependent on several variables. This review delved into the various variable affecting the pyrolysis of waste plastics and how they can be optimized to obtain the best oil quality, yield and how the process can be effectively optimized.

\section{Yield and Process Parameters}

The product yield and composition during pyrolysis are affected by the parameters applied during the process such as catalyst type, temperature, time, type of reactors used and rate of fluidizing gas. Thermal degradation plays a very important role in the degradation of plastics during pyrolysis and different plastics have different degradation temperatures. The types of plastic determine such properties such as configurational, conformational and chemical structure of the plastics which plays a very important role in the degradation process [10-14]. Temperature applied during the pyrolytic breakdown is also dependent on the end product desired as indicated in Table 1. When gaseous or char was desired higher temperature over $500{ }^{\circ} \mathrm{C}$ was applied during the degradation process, however if liquid yields were preferred temperatures ranging from $300-500{ }^{\circ} \mathrm{C}$ were recommended $[15,16]$.

Table 1. Onset degradation temperature (א) of some commonly used plastics [10-14].

\begin{tabular}{llllll}
\hline Plastics & Time/min & si & Liquid \% & Char \% & Gases\% \\
\hline LDPE & 70 & 280 & 92.16 & 2.10 & 5.74 \\
HDPE & 75 & 310 & 90.06 & 1.60 & 8.34 \\
PP & 90 & 260 & 89.98 & 3.65 & 6.37 \\
PS & 60 & 260 & 82.04 & 16.07 & 1.89 \\
PET & 76 & 400 & 88.00 & 5.00 & 7.00 \\
PVC & 70 & 220 & 80.00 & 7.00 & 13.00 \\
\hline
\end{tabular}

The reactor type and set up also plays a very important role in the in achieving the desired end product. The production process may be by continuous flow process, semi batch or batch reactors. Every reactor has its advantages and disadvantages and the particular brand will be selected based on the fact that it will give the most efficient cost effective result for the desired end products targeted. Batch reactors have the advantage of having flexible and easy control but the disadvantage includes its unsuitability for catalytic pyrolytic degradation because of formation of contaminants (coke) on the surface of the catalyst reducing the total efficiency of the process. Fluidized bed reactors offer good productivity when catalytic pyrolysis is done because it offers the flexibility of utilizing the catalyst over and over again without contamination offering good cost efficiency considering the fact that catalyst are very costly. However, generally challenges encountered during the operation of pyrolytic reactors include the handling of many pumps that are used to manufacture the plant, feeding method of catalyst introduction, catalytic efficiency of the process (discharge or reuse), process control for products and efficiency of collecting product yield [17-19]. In addition the pressure and residence time also affect the quantity yield, ratio of the yield products and quality of yield. Higher pressure increase the gaseous yield but the molecular weight distribution of the liquid and gaseous product obtained are affected. However, some researchers carry out their pyrolysis of waste plastics at atmospheric pressure and depend more on temperature variation to achieve desired results. Pressure and residence time are very important factors that would be taken into consideration when pyrolytic degradation of waste plastics is to be carried out. 


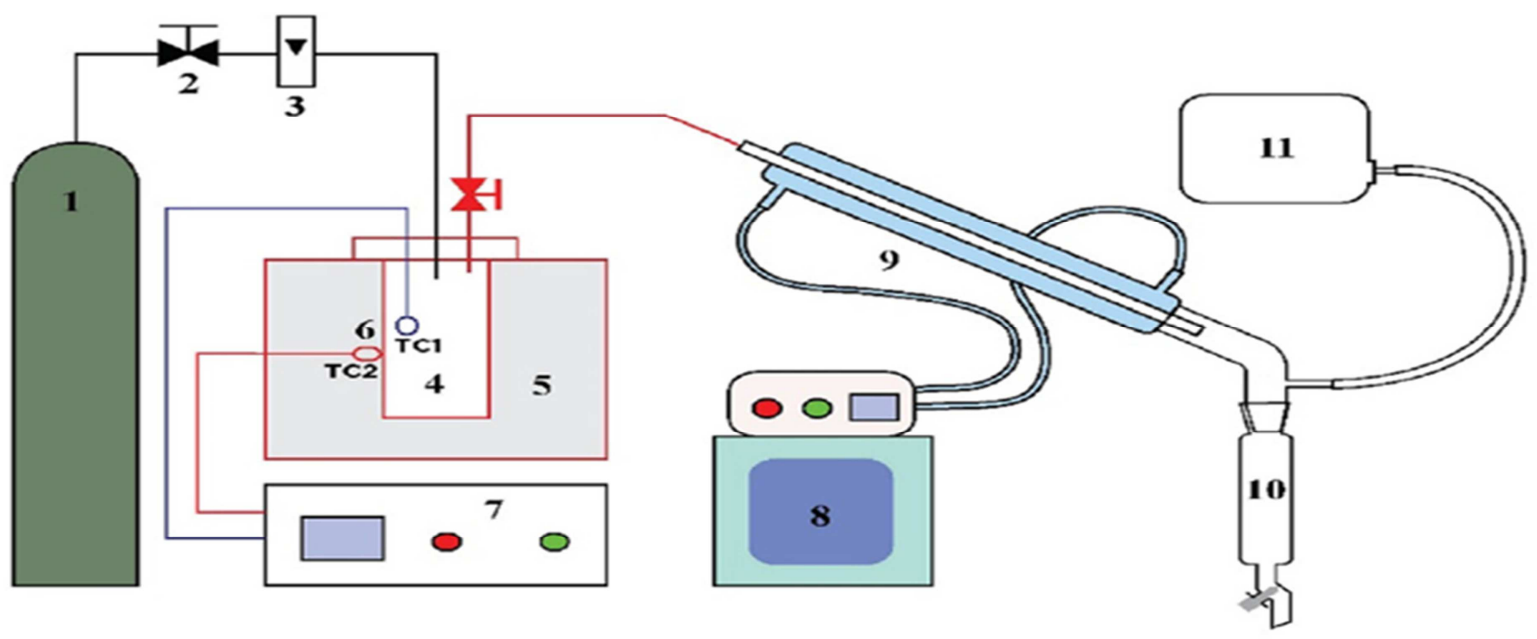

Figure 1. Simple representation of Pyrolytic setup (11: Tedler Bag; 10: Seperatory funnel; 9: Condenser; 8: Chiller; 7: PID controller; 6: Temperature regulator [TC2 and TC1, are outside and inside the reactor respectively; 5: Tubular furnace, 4: Reactor; 3: Flow meter; 2: Adjustable valve; and 1: $N_{2}$ cylinder $[17,18])$.

The type of fluidising gas (inert gas) e.g. nitrogen, helium, ethylene, propylene, hydrogen, argon and its rate of application during the pyrolytic degradation process also play a very important role end product obtained, the role this gas plays is to transport the gaseous products without taking part in the pyrolysis. Nitrogen is commonly utilized as fluidizing gas in plastic pyrolysis because it's safer and easier to handle than other gases. In a related study they found that the rate of degradation was reduced at a low flow rate fluidization of $300 \mathrm{ml} / \mathrm{min}[20,21]$. At very high flow rate $900 \mathrm{ml} / \mathrm{min}$ the hydrocarbon and gasoline fractions were maximized. This showed the effects of fluidizing gas on the type of yield and products obtained after pyrolytic degradation of waste plastics. Catalyst plays a significant role in the degradation process to speed up chemical reaction and improve the yield of the waste plastics under pyrolytic action, as much as possible the target is to produce the products (gasoline, diesel and gas) that have almost similar properties with convectional ones. Some catalysts used for this process include; silica-alumina; fluid cracking catalyst (FCC) and Zeolites. Zeolites catalyst offer some advantages such as reduction in the impurities in oil obtained after the pyrolysis [22].

The use of FCC catalyst also has a significant improvement in the conversion during plastic pyrolysis, according to a related study Kyong et al., [23] the solid ash content reduced by 4.5 to 0.9 wt $\%$ with the use of FCC catalyst indicating an improvement in conversion of liquefied yield. Amorphous acidic silica-alumina catalyst have great influence in the final product as a result of the pyrolytic products of the waste plastics depending on the acidity which is determined by the mole ration of the $\mathrm{SiO}_{2} / \mathrm{Al}_{2} \mathrm{O}_{3}$. In a related study Sakata et al., [24] found out that SA-2 catalyst with lower acidity produced greater quantity of liquid oil (74.3 wt $\%$ ) compared to $67.8 \mathrm{wt} \%$ and $49.8 \mathrm{wt} \%$ for SA-1 and ZSM-5 respectively on the pyrolysis of High Density Polyethylene (HDPE). There are strong acid sites in ZSM-5 catalyst and as a result produced more gaseous products yields than the other two catalyst (SA-1 and SA-2), however produced lower liquid yields.

In a related study López et al., [25] zeolite (ZSM-5) catalyst has a strong influence in the pyrolysis products of waste plastics. It generated higher proportion of gases and liquids at $\left(440^{\circ} \mathrm{C}\right.$ and $\left.500^{\circ} \mathrm{C}\right)$ with a higher content of aromatics compared to the pyrolysis done without catalyst, however a higher temperature is needed by Red Mud to produce a pronounced effect in catalysing the pyrolysis of waste plastics, in the same study it was discovered that the same results are obtained without catalyst at $440^{\circ} \mathrm{C}$, and at $500^{\circ} \mathrm{C}$ a higher yield of gases and aromatics in the liquids was obtained. Thus zeolite catalyst maximizes the production of gaseous yield, while silica -alumina and FCC maximized liquid yields in the pyrolysis of waste plastics.

\section{Properties of Oil from Pyrolysis of Waste Plastics}

Calorific value of Polypropylene (PP), High Density Polyethylene (HDPE) and Low density Polyethylene (LDPE) were higher than $40 \mathrm{MJ} / \mathrm{kg}$ (Table 2). This was considered as very high energy requirements for pyrolysis of these waste plastics. However the calorific value of Polystyrene (PS) is lower than the former due to the presence of aromatic ring in the chemical structure of PS creating a lower combustion energy required for its pyrolysis compared to the aliphatic hydrocarbon [26]. Table 1 also showed that Polyvinyl chloride (PVC) and Polyethylene terephthalate (PET) indicated lower calorific value below $30 \mathrm{MJ} / \mathrm{kg}$. This was as a result of presence of some functional groups in the polymers such as the presence of chlorine group and benzoic group in PVC and PET respectively. Table 2 also indicated that the properties of oil obtained due to pyrolysis of waste plastics was similar to conventional petroleum motor spirits and automotive gas oil indicating the great potential of 
pyrolytic waste plastics oil.

Table 2. Properties of Oil from Pyrolysis of Waste Plastics [27].

\begin{tabular}{|c|c|c|c|c|c|c|c|c|}
\hline \multirow{2}{*}{ Properties } & \multicolumn{8}{|l|}{ Plastics } \\
\hline & Diesel & Gasoline & PS & PP & LDPE & PVC & HDPE & PET \\
\hline Diesel index & 40 & - & n.a & 34.35 & n.a & n.a & 31.05 & n.a \\
\hline Aniline point $\left({ }^{\circ} \mathrm{C}\right)$ & 77.5 & 71 & n.a & 40 & n.a & n.a & 45 & n.a \\
\hline Flash Point & 52 & 42 & 26.1 & 30 & 41 & 40 & 48 & n.a \\
\hline Pour Point & 6 & - & -67 & -9 & n.a & n.a & -5 & n.a \\
\hline Octane number RON (min) & - & $91-95$ & $90-98$ & 97.8 & n.a & n.a & 95.5 & n.a \\
\hline Octane number MON (min) & - & $81-85$ & n.a & 87.6 & n.a & n.a & 85.3 & n.a \\
\hline Density@15 ${ }^{\circ} \mathrm{C}(\mathrm{g} / \mathrm{cm} 3)$ & 0.807 & 0.780 & 0.85 & 0.86 & 0.78 & 0.84 & 0.89 & 0.90 \\
\hline Viscosity $\left(\mathrm{mm}^{2} / \mathrm{s}\right)$ & $1.9-4.1$ & 1.17 & $1.4^{\mathrm{d}}$ & $4.09^{\mathrm{a}}$ & 5.56 & $6.36^{\mathrm{b}}$ & 5.08 & $\mathrm{n} . \mathrm{a}$ \\
\hline API gravity@60F & 38 & 55 & n.a & 33.03 & 47.75 & 38.98 & 27.48 & n.a \\
\hline Calorific value (MJ/kg) & 43.0 & 42.5 & 43.0 & 40.08 & 39.5 & 21.1 & 40.5 & 28.2 \\
\hline
\end{tabular}

n.a $=$ not available in literature; ${ }^{a, b, c}$ and ${ }^{d}$ represent viscosities at $40,30,25$ and $50^{\circ} \mathrm{C}$ respectively

\section{Further Discussions on Pyrolysis of Waste Plastics}

Table 3 showed the temperature required to optimize the yields in the catalytic pyrolytic degradation at different operating conditions. Other variables identified that play crucial roles include: type of reactor, pressure, temperature, rate of application of heat, residence time during the pyrolytic process of the waste plastics. All the experiment carried out under this review depicted in Table 3 was done using nitrogen as the fluidising agent. PET and PVC recorded the lowest yield of liquid oil compared with the other plastics reducing the interest of researchers to explore these plastics for pyrolytic purposes. Not all plastics are suitable for pyrolytic purposes such as PVC because it produces harmful hydrochloric acid during pyrolysis. In addition oil produced contains chlorinated compounds that will reduce the quality of the oil and also make it toxic and dangerous to the environment and also to humans.

Table 3 also showed that optimization of pyrolytic effects in waste plastics can take place effectively at temperatures between the ranges of $500-550^{\circ} \mathrm{C}$; however this can be reduced to $450^{\circ} \mathrm{C}$ with the application of catalyst with higher yield in the liquid portion of the product. The application of catalyst improved the yield of most of the plastics as depicted in Table 3 with PS showing exceptionally qualities in the sense that it degraded very well without any catalyst yet achieved a $97 \mathrm{wt} \%$ of oil [27] showing the best plastics that can be easily applied in the pyrolytic process of for waste plastics. Comparing the polyolefins LDPE gave the largest oil of $93 \mathrm{wt} \%$ yield, while HDPE gave $84.7 \mathrm{wt} \%$ yield and PP was the least with $82.12 \mathrm{wt} \%$ yields during thermal pyrolytic degradation. Addition of catalyst such as FCC at the correct temperature will further maximize the oil yield to 90 wt $\%$.

Table 3. Pyrolysis of Waste Plastic Studies.

\begin{tabular}{|c|c|c|c|c|c|c|c|c|c|}
\hline \multirow[b]{2}{*}{$\begin{array}{l}\text { Type of } \\
\text { plastic }\end{array}$} & \multirow[b]{2}{*}{ Reactor Type } & \multicolumn{7}{|c|}{ Parameters } & \multirow[b]{2}{*}{ More info } \\
\hline & & Temp C & Pressure & $\begin{array}{l}\text { Rate of } \\
\text { Heating } \\
\text { (C/min) }\end{array}$ & $\begin{array}{l}\text { Residence } \\
\text { time (min) }\end{array}$ & Oil & Gas & Char & \\
\hline PET [28] & Fixed bed & 500 & - & 10 & - & 23.1 & 76.9 & 0 & \\
\hline PET [29] & - & 500 & $1 \mathrm{~atm}$ & 6 & - & 38.9 & 52.1 & 8.9 & \\
\hline HDPE [30] & Horizontal steel & 350 & - & 20 & 30 & 80.9 & 17.2 & 1.9 & \\
\hline HDPE [31] & Semi-batch & 400 & $1 \mathrm{~atm}$ & 7 & - & 82 & 16 & 2 & $\begin{array}{l}\text { Stirred @ 200rpm, } \\
\text { FCC catalyst } 10 \\
\text { wt } \%\end{array}$ \\
\hline HDPE [32] & Batch & 450 & - & - & 60 & 74.5 & 5.8 & 19.7 & \\
\hline HDPE [33] & Semi-batch & 450 & 1atm & 25 & - & 91.2 & 4.1 & 4.7 & $\begin{array}{l}\text { Stir@ @ 50rpm, } \\
\text { FCC catalyst } 20 \\
\text { wt } \%\end{array}$ \\
\hline HDPE [33] & Fluidised bed & 500 & - & - & 60 & 85 & 10 & 5 & Si-Al Catalyst \\
\hline HDPE [34] & Batch & 550 & - & 5 & - & 84.7 & 16.3 & 0 & \\
\hline HDPE [35] & Fluidised bed & 650 & - & - & $20-25$ & 68.5 & 31.5 & 0 & \\
\hline PVC [28] & Fixed bed & 500 & - & 10 & - & 12.3 & 87.7 & 0 & \\
\hline PVC [36] & Vacuum batch & 520 & $2 \mathrm{kPa}$ & 10 & - & 12.8 & 0.34 & 28.1 & $\begin{array}{l}\mathrm{HCl}=58.2 \mathrm{wt} \% \\
\text { yield }\end{array}$ \\
\hline LDPE [26] & $\begin{array}{l}\text { Pressurized } \\
\text { batch }\end{array}$ & 425 & $0.8-4.3 \mathrm{Mpa}$ & 10 & 60 & 89.5 & 10 & 0.5 & \\
\hline LDPE [37] & Batch & 430 & - & 3 & - & 75.6 & 8.2 & 7.5 & $\begin{array}{l}\text { Wax }=8.7 \mathrm{wt} \% \\
\text { yield }\end{array}$ \\
\hline LDPE [29] & - & 500 & 1atm & 6 & - & 80.4 & 19.4 & 0.2 & \\
\hline
\end{tabular}




\begin{tabular}{|c|c|c|c|c|c|c|c|c|c|}
\hline \multirow[b]{2}{*}{$\begin{array}{l}\text { Type of } \\
\text { plastic }\end{array}$} & \multirow[b]{2}{*}{ Reactor Type } & \multicolumn{7}{|c|}{ Parameters } & \multirow[b]{2}{*}{ More info } \\
\hline & & Temp C & Pressure & $\begin{array}{l}\text { Rate of } \\
\text { Heating } \\
(\mathrm{C} / \mathrm{min})\end{array}$ & $\begin{array}{l}\text { Residence } \\
\text { time (min) }\end{array}$ & Oil & Gas & Char & \\
\hline LDPE [38] & Fixed bed & 500 & - & 10 & 20 & 95 & 5 & 0 & \multirow{5}{*}{$\mathrm{Wax}=24.8 \mathrm{wt} \%$} \\
\hline LDPE [34] & Batch & 550 & - & 5 & - & 93.1 & 14.6 & 0 & \\
\hline LDPE [39] & Fluidised bed & 600 & $1 \mathrm{~atm}$ & - & - & 51.0 & 24.2 & 0 & \\
\hline PP [30] & Horizontal steel & 300 & - & 20 & 30 & 69.8 & 28.8 & 1.3 & \\
\hline PP [40] & Batch & 380 & $1 \mathrm{~atm}$ & 3 & - & 80.1 & 6.6 & 13.3 & \\
\hline PP [31] & Semi-batch & 400 & $1 \mathrm{~atm}$ & 7 & - & 85 & 13 & 2 & \multirow{2}{*}{$\begin{array}{l}\text { Stir@200rpm, } \\
\text { FCC } 10 \text { wt } \% \\
\text { Stir@ @ 50rpm, } \\
\text { FCC10 wt } \%\end{array}$} \\
\hline PP [33] & Semi-batch & 450 & $1 \mathrm{~atm}$ & 25 & - & 92.3 & 4.1 & 3.6 & \\
\hline PP [29] & - & 500 & $1 \mathrm{~atm}$ & 6 & - & 82.1 & 17.76 & 0.12 & \multirow[b]{3}{*}{$\begin{array}{l}\text { Stir@200 rpm, } \\
\text { FCC, Cat/pol=10 } \\
\text { w/w }\end{array}$} \\
\hline PP [41] & Batch & 740 & - & - & - & 48.8 & 49.6 & 1.6 & \\
\hline PS [31] & Semi-batch & 400 & $1 \mathrm{~atm}$ & 7 & - & 90 & 6 & 4 & \\
\hline PS [26] & $\begin{array}{l}\text { Pressurized } \\
\text { batch }\end{array}$ & 425 & $0.31-1.6 \mathrm{Mpa}$ & 10 & 60 & 97 & 2.50 & 0.5 & \multirow{3}{*}{$\begin{array}{l}\text { Zn catalyst, } \\
\text { Cat } / \text { pol }=5 \mathrm{w} / \mathrm{w} \\
\text { Styrene }+64.9 \\
\text { wt } \% \text { oil }\end{array}$} \\
\hline PS [42] & Batch & 500 & - & - & 150 & 96.7 & 3.27 & 0 & \\
\hline PS [41] & Batch & 581 & - & - & - & 89.5 & 9.9 & 0.6 & \\
\hline
\end{tabular}

In Table 3: Nitrogen gas was used as fluidizing medium.

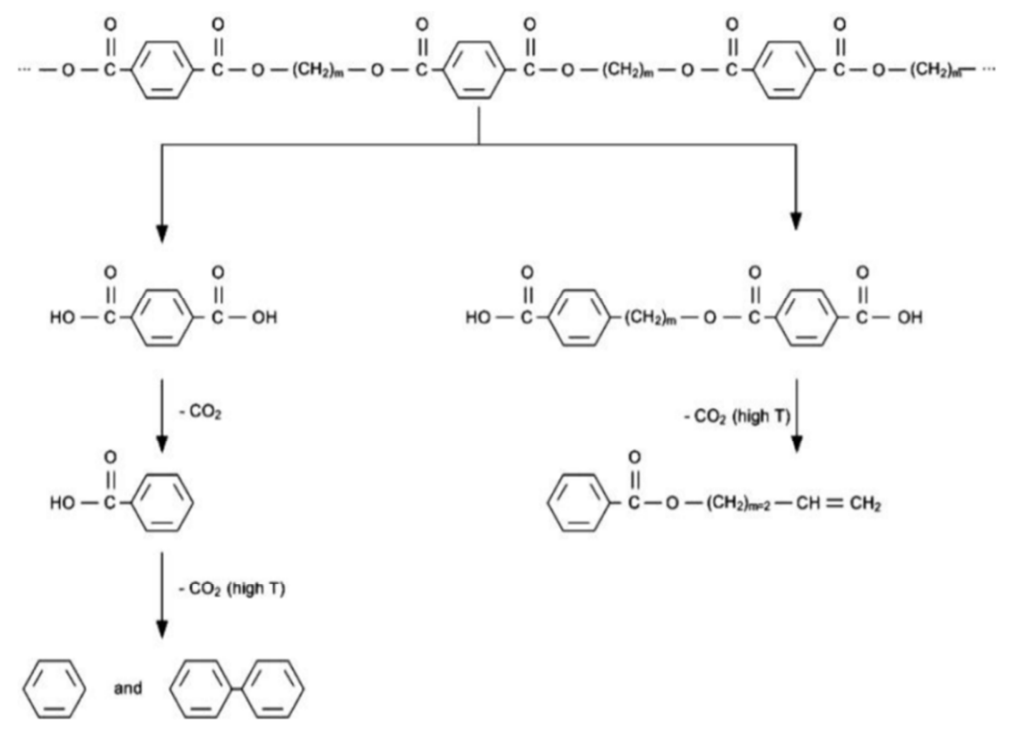

(a)
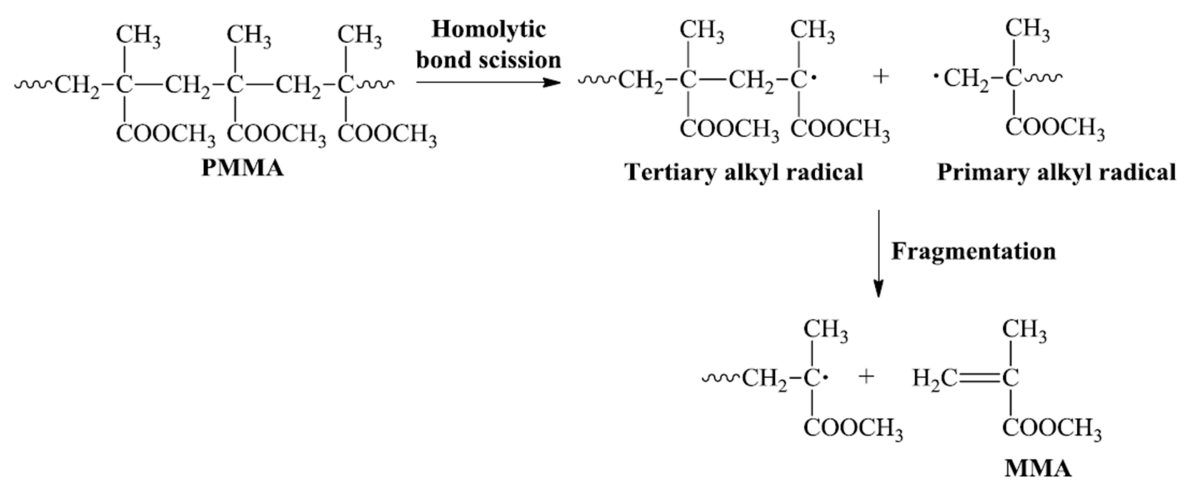

(b)

Figure 2. (a). Sample pyrolytic break down of PET [45-48], (b). Sample pyrolytic degradation of PMMA [44]. 


\section{Conflict of Interest}

The authors declare that they have no competing interest.

\section{References}

[1] Association of Plastic Manufacturers Europe. (2015). An analysis of European plastics production, demand and waste data. European Association of Plastics Recycling and Recovery Organisations, Belgium, 1-32.

[2] Moustakas, K., and Loizidou, M. (2010) Solid waste management through the application of thermal methods. in: S. Kumar, (Ed.). Waste Management. InTech, Greece, 89-124.

[3] Patni, N., Shah, P., Agarwal, S., and Singhal, P. (3013). Alternate Strategies for Conversion of Waste Plastic to Fuels. ISRN Renewable Energy, 1-7.

[4] Meier D. (2019). Pyrolysis Oil Biorefinery. Adv Biochem Eng Biotechnol, 166: 301-337. doi: 10.1007/10_2016_68. PMID: 28289770 .

[5] Vermeulen, I., Van Caneghem, J., Block, C., Baeyens, J., and Vandecasteele, C.( 2011). Automotive shredder residue (ASR) reviewing its production from end-of-life vehicles (ELVs) and its recycling, energy or chemicals' valorisation. J. Hazard., Mater. 190, 8-27.

[6] Al-Salem, S., Lettieri, P., Baeyens, J. (2009a). Recycling and recovery routes of plastic solid waste (PSW): a review. Waste Manage. 29, 2625-2643.

[7] Al-Salem, S., Lettieri, P., Baeyens, J. (2009b). Thermal treatment of different grades and types of Polyethylene (PE) wasted articles. In: Proceedings of 8th World Congress of Chemical Engineering Montreal (Quebec), pp. 1-4.

[8] Al-Salem, S., Lettieri, P., Baeyens, J.( 2010). The valorization of plastic solid waste (PSW) by primary to quaternary routes: from re-use to energy and chemicals. Prog. Energy Combust. Sci. 36, 103-129.

[9] Bridgwater. A. V. (2012) Review of fast pyrolysis of biomass and product upgrading. Biomass Bioenergy. 38, 68-94.

[10] Erdogan, S. (2020). Recycling of Waste Plastics into Pyrolytic Fuels and Their Use in IC Engines. IntechOPen. 1-23. DOI: http://dx.doi.org/10.5772/intechopen.90639

[11] Abnisa, F., Wan Daud, W. M. A., Arami-Niya, A., Ali, B. S., Sahu, J. N. (2014). Recovery of liquid fuel from the aqueous phase of pyrolysis oil using catalytic conversion. Energy \& Fuels, 28 (2014), 3074- 3085.

[12] S D A Sharuddin, F Abnisa, W M A W Daud and M KAroua. (2018). Pyrolysis of plastic waste for liquid fuel production as prospective energy resource. IOP Conf. Series: Materials Science and Engineering 334, 1- 9. Doi: 012001 doi: $10.1088 / 1757-899 X / 334 / 1 / 012001$

[13] Ansah, E., Wang, L., and Shahbazi, A. (2016). Thermogravimetric and calorimetric characteristics during copyrolysis of municipal solid waste components. Waste Management, 58, 196-206, http://dx.doi.org/10.1016/j.wasman.2016.06.015
[14] Ibrahi, H., Ahmed, M, A. H., Ahmed, S. M., Mohmmed, R., and Motawie, A. M. (2018). Thermal Degradation of Four Types of Plastic Solid Waste HDPE, LDPE, PP and PS. 1-16. Retrieved from file:///C:/Users/user/Downloads/Thermaldegradationoffourtyp esofPlasticwaste.pdf.

[15] Sharuddin, A. S. D., Abnisa, F., Wan Daud, W. M. A., and Aroua, M. K. (2016). A review on pyrolysis of plastic wastes. Energy Convers Manage. 115, 308-26.

[16] Abnisa, F., Sharuddin, A. S. D., Wan. W. M. A Daud. (2017). Optimizing the use of biomass waste through co- pyrolysis. INFORM - International News on Fats, Oils, and Related Materials. American oil chemists' society Press. pp. 16-9.

[17] Fogler. H. S (2010). Elements of chemical reaction engineering. 4th ed. Pearson Education Inc., New Jersey. Butler, E., Devlin, G., and McDonnell, K., (2011). Waste polyolefins to liquid fuels via pyrolysis: review of commercial state-of-the-art and recent laboratory research. Waste Biomass Valoriz. 2, 227-255.

[18] Ragaert, K., Delva, L., and Geem, K. V. (2017). Mechanical and chemical recycling of solid plastic waste. Waste Management. http://dx.doi.org/10.1016/j.wasman.2017.07.044.

[19] Lin, Y. H., and Yang, M. H. (2007). Catalytic pyrolysis of polyolefin waste into valuable hydrocarbons over reused catalyst from refinery FCC units. Applied Catalysis A: General. 328 (2007) 132-9.

[20] Y. H. Lin, and Yen, H. Y. (2005). Fluidised bed pyrolysis of polypropylene over cracking catalysts for Producing hydrocarbons. Polym Degrad Stab. 89 (2005) 101-8.

[21] Miskolczi, N., Angyal, A., Bartha, L., and Valkai. I. (2009). Fuels by pyrolysis of waste plastics from Agricultura and packaging sectors in a pilot scale reactor. Fuel Process $\begin{array}{llll}\text { Technol. } & 90 & \text { (2009) } & \text { 1032-40. }\end{array}$ https://doi.org/10.1016/j.fuproc.2009.04.019.

[22] Kyong, H. L., Sang, G. J., Kwang, H. K., Nam, S. N., Dae, H. S., and Park, J. (2003). Thermal and catalytic degradation of waste high density polyethylene (HDPE) using spent FCC catalyst. Korean J Chem Eng. 20 (2003) 693-7.

[23] Sakata, Y., Uddin, M. A., Muto, A., Kanada, Y., and Koizumi, K. and Murata, K. (1997). Catalytic degradation of polyethylene into fuel oil over mesoporous silica (KFS-16) catalyst. J Anal Appl Pyrolysis. 43 (1) 15-25. DOI: 10.1016/S0165-2370(97)00052-1

[24] López, A., de Marcoa, I., Caballeroa, B. M., Laresgoiti, M. F., Adrados, A., and Aranzabal, A. (2011) Catalytic pyrolysis of plastic wastes with two different types of catalysts: ZSM-5 zeolite and Red Mud. Applied Catalysis B: Environmental. 104 (3-4), 211-219. Doi: 10.1016/j.apcatb.2011.03.030

[25] Onwudili, J. A., Insura, N., P. T. Williams, P. T. (2009). Composition of products from the pyrolysis of polyethylene and polystyrene in a closed batch reactor: Effects of temperature and residence time. J Anal Appl Pyrolysis. 86, 293-303.

[26] Li, C., Zhang, C., Gholizadeh, M., and Hu, X. (2020). Different reaction behaviours of light or heavy density polyethylene during the pyrolysis with biochar as the catalyst, Journal of Hazardous Materials, Doi: 10.1016/j.jhazmat.2020.123075, (123075). 
[27] Cepeliogullar, O., and Putun. A. E. (2013). Utilization of two different types of plastic wastes from daily and industrial life. in: Ozdemir, C., Sahinkaya, S., Kalipci, E., Oden, M. K., (Eds.), ICOES Cappadocia 2013. ICOEST Cappadocia, Turkey, pp. 1-13.

[28] Fakhrhoseini, S, M., and Dastanian, M. (2013). Predicting pyrolysis products of PE, PP, and PET using NRTL activity coefficient model. Hindawi Publishing Corporation. 2013 (2013) 1-5.

[29] Ahmad, I., Khan, M. I., Khan, H., Ishaq, M., Tariq., and Gul, K. (2014). Pyrolysis Study of Polypropylene and Polyethylene Into Premium Oil Products. Int J Green Energy. 12, 663-71.

[30] Kyong, H. L., Nam, S, N., Dae, H. S and Seo, Y. (2002). Comparison of plastic types for catalytic degradation of waste plastics into liquid product with spent FCC catalyst. Polym Degrad Stab. 78, 539- 44.

[31] Abbas-Abadi, M. S., Haghighi, M. N., and Yeganeh, H. (2013) Evaluation of pyrolysis product of virgin high density polyethylene degradation using different process parameters in a stirred reactor. FueProcess Technol. 109, 90-5.

[32] Luo, G., Suto, T., Yasu, S., and Kato, K.(2000). Catalytic degradation of high density polyethylene and polypropylene into liquid fuel in a powder-particle fluidized bed. Polym Degrad Stab. 70, 97-102.

[33] Marcilla, A., Beltrán, M. I., Navarro, R.(2009). Thermal and catalytic pyrolysis of polyethylene over HZSM5 and HUSY zeolites in a batch reactor under dynamic conditions. Applied Catalysis B Environmental. 86, 78-86.

[34] Mastral, F. J., Esperanza, E., Garcia, P., M. Juste, M. (2001). Pyrolysis of high-density polyethylene in a fluidized bed reactor. Influence of the temperature and residence time. $J$ Anal Appl Pyrolysis. 63, 1-15.

[35] Miranda, R., Jin, Y., Roy, C., Vasile, C,. (1998). Vacuum pyrolysis of PVC kinetic study. Polym Degrad Stab. 64, 12744.

[36] Uddin, M. A., Koizumi, K., Murata, K., and Sakata, Y. (1996). Thermal and catalytic degradation of structurally different types of polyethylene into fuel oil. Polym Degrad Stab. 56, $37-44$.
[37] R. Bagri, R., and Williams, P. T. (2001) Catalytic pyrolysis of polyethylene. J Anal Appl Pyrolysis. 63, 29-41.

[38] Williams, P. T., and Williams, E. A. (1998). Fluidised bed pyrolysis of low density polyethylene to produce petrochemical feedstock. J Anal Appl Pyrolysis. 51, 107-26.

[39] Sakata, Y., Uddin, M. A., and Muto, A. (1999). Degradation of polyethylene and polypropylene into fuel oil by using solid acid and non-solid acid catalysts. J Anal Appl Pyrolysis. 51 (1999) 135-55.

[40] Demirbas. A. (2004). Pyrolysis of municipal plastic wastes for recovery of gasoline-range hydrocarbons. J Anal Appl Pyrolysis. 72, 97-102.

[41] Adnan, J. and Jan. M. R. S. (2014). Thermo-catalytic pyrolysis of polystyrene in the presence of zinc bulk catalysts. Journal of the Taiwan Institute of Chemical Engineers. 45 (2014) 2494-500

[42] Bennet, F., Hart-Smith, G., Gruendling, T., Davis, T. P., Barker P. J., Barner-Kowollik, C., 2010. Degradation of poly(methyl methacrylate) model compounds under extreme environmental conditions. Macromol. Chem. Phys. 211, 1083-1097.

[43] Çepelioğullar, O., and Pütün, E. A. (2013). Thermal and kinetic behaviors of biomass and plastic wastes in copyrolysis, Energy Conversion and Management, 75, 263-270, ISSN 0196-8904. Doi: https://doi.org/10.1016/j.enconman.2013.06.036.

[44] Vijayakumar, A., and Sebastian, J. (2018). Pyrolysis process to produce fuel from different types of plastic - a review. Materials Science and Engineering, 396, 1-9. Doi: 012062 doi: 10.1088/1757-899X/396/1/012062.

[45] Brems, A., Baeyens, J., Vandecasteele, C., and Dewil, R. (2011). Polymeric Cracking of Waste Polyethylene Terephthalate to Chemicals and Energy, Journal of the Air \& Waste Management Association, 61: 7, 721-731, DOI: 10.3155/1047-3289.61.7.72. 